\title{
DIE OPERASIONALISERING VAN 'N MODEL VIR DIE ONTWIKKELING VAN KLINIESE VERPLEGINGSTANDAARDE
}

\author{
T VAN DER MERWE EN M MULLER
}

\section{UITTREKSEL}

Een van die vereistes van ' $n$ verpleegmodel is die praktiese implementering daarvan in die spesifieke domein van verpleging. Die doel van hierdie artikel is die beskrywing van die implementering/operasionalisering, asookdie evaluering van ' $n$ model vir die ontwikkeling van verplegingstandaarde in ' $n$ verpleegdiens. ' $n$ Verkennende en beskywende navorsingsontwerp is uitgevoer, met 'n eenvoudige loodsstudie waartydens 9 verpleegkandiges skriftelik versoek is om hul mening oor die model te beskryf. Die model is suksesvol in ' $n$ verpleegdiens van ' $n$ akademiese hospitaal geüplementeer. Evaluering het getoon dat die implementering gehalteverpleging, die hersosialisering van woardes en professionele en persoonlike ontwikkeling van die verpleegkundige fasilizeer.

\section{ABSTRACT}

One of the requirements for a nursing model in any field of nursing is its practical implementation. The purpose of this article is to describe how the model for the development of nursing standards in a nursing service was implemented and evaluated An exploratory and descriptive research design was followed, with a simple pilot study during which 9 nurses were requested to give their view on the model. The model was sucessfully implemented in the nursing service of an academic hospital. Evaluation revealed that the implementation facilitated quality nursing, the resocialising of values and the professional and personal growth of nurses in that nursing service.

\section{NLEIDING}

'n Model vir die ontwikkeling van kliniese verplegingstandaarde is deur middel van ' $n$ teoriegenererende navorsingsontwerp ontwikkel en beskryf. Die doel met die model vir die ontwikkeling van verplegingstandaarde in "n hospitaalgemeenskap is drieërlei van aard: voortreflike standaardontwikkeling fasiliteer gehalteverpleging in die verpleegdiens, die hersosialisering van waardes (veral ten opsigte van gehalteverpleging) en die professionele en persoonlike ontwikkeling van verpleegkundiges.

Evaluering ten opsigte van die sentraalteoretiese aanname vir die model sal geskied deur middel van 'n vraelys met ' $n$ enkelvraag aan respondente wat die driedaagse kursus ter voorbereiding vir die ontwikkeling van verplegingstandaarde deurloop het en intensief betrokke was by die formulering en implementering van verplegingstandaarde in die betrokke verpleegdiens. Gedeeltelike operasionalisering van die model het reeds in Desember 1990 in aanvang geneem, maar die navorser is eers vanaf 1992 aktief betrokke by die projek oor die ontwikkeling van verplegingstandaarde. Die doel met hierdie artikel is om die operasionalisering van die model en die gepaardgaande resultate te beskryf.

\section{Sentraalteoretiese aanname vir die model}

In hierdie studie word nie ' $\mathrm{n}$ hipotese gestel nie. Die suksesvolle implementering of operasionalisering van die model vir die ontwikkeling van verplegingstandaarde word deur die volgende sentraalteoretiese aanname gerig: Die verpleegdiensbestuurder fasiliteer gehaiteverpleging deur die ontwikkeling van verplegingstandaarde. Die ontwikkeling van verplegingstandaarde dra by tot die hersosialisering van die verpleegkundige met betrekking tot waardes oor gehalteverpleging, soos gereflekteer in die standaarde, asook die professionele en persoonlike ontwikkeling van die verpleegkundige.

\section{DEFINISIES}

Definisies van toepassing op hierdie gedeelte van die studie is die volgende:

\section{Operasionalisering}

Operasionalisering verwys na die praktiese implementering van ' $n$ model en die evaluering daarvan ten opsigte van die sentraalteoretiese aannames wat gestel is.

\section{Hersosialisering van waardes}

Die hersosialisering van waardes impliseer die kennis geïnternaliseer ten opsigte van standaarde as deel van gehalteverpleging, deur die verpleegkundige, tydens die proses van standaardontwikkeling.

Nuwe verpleegkundiges

Nuwe verpleegkundiges verwys na die geregistreerde verpleegkundiges wat vir die eerste keer in die spesifieke verpleegdiens of hospitaalgemeenskap in diens geneem word

Spesifieke hospitaalgemeenskap

in Spesifieke hospitaalgemeenskap impliseer in hierdie studie die verpleegdiens in " $n$ akademiese hospitaal waar die model geoperasionaliseer is.

\section{NAVORSINGSONTWERP VIR DIE OPERASIONALISERING VAN DIE MODEL}

'n Verkennende, beskrywende en gedeeltelik evaluerende studie is deur middel van 'n eenvoudige loodsstudie uitgevoer. Die model is in ' $n$ verpleegdiens van ' $n$ akademiese hospitaal in Gauteng geoperasionaliseer. Die proses van standaardontwikkeling is vanuit die personeel-ontwikkelingsdepartement oor 'n tydperk van twee jaar in geselekteerde verplegingseenhede in die verpleegdiens uitgevoer. Die kursus- gangers (belangstellende professionele verpleegkundiges en eenheidsbestuurders) het 'n gestruktureerde opleidingsprogram oor standaardformulering deurloop. Daarna is die proses van standaardformulering in die verplegingseenhede deur die navorser begelei.

Die teikenpopulasie vir die loodsstudie is verpleegkundiges van die spesifieke hospitaal wat die kursus vir die ontwikkeling van verplegingstandaarde suksesvol deurloop het en aan die proses van standaardontwikkeling deelgeneem het. Die steekproeftrekking het op die eenheidsbestuurders gefokus.

Die volgende insluitingskriteria vir die loodsstudie is gestel:

* Verpleegkundiges het nie hul verpleeg. opleiding by die spesifieke hospitaal ondergaan nie.

* Verpleegkundiges het die kursus ter "voor-bereiding van standaard- ontwikkeling" suksesvol deurloop.

* Betrokkenheid by die projek oor standaard-ontwikkeling vanaf 1990 , dit wil sê die volle tydperk van twee jaar. 


\section{Data-insameling en -hantering}

Data-insameling het deur middel van skriftelike semi-gestruktureerde vraagstelling plaasgevind. Die navorser het die doel van die studie verduidelik en verpleegkundiges is deur middel van ' $n$ enkele vraag gevra om hulle beskouing van die projek te beskryf.

Data-insameling is deur die navorser self gedoen, en om vertrouenswaardigheid te verhoog, is respondente gevra om hulleself nie te identifiseer nie en die vraelyste aan die sekretaresse in die personeelontwikkelingsafdeling te oorhandig. Vraagstelling het gedurende Maart 1994 buite die personeelontwikkelingsafdeling plaasgevind. Voltooiing van die vraag het gemiddeld 30 minute geduur, en tien verpleegkundiges is gevra om deel te neem. Die tiende respondent is ongelukkig in hierdie tydperk oorlede en net nege respondente het dus deelgeneem. Datahantering is gedoen deur middel van gestruktureerde vraelyste wat respondente onafhanklik in hulle eie tyd kon invul.

\section{Operasionalisering van die model}

Die ontwikkeling van verplegingstandaarde vind op verskillende posvlakke en tussen verskeie rolspelers plaas, naamlik:

* 'n hoofverpleegdiensbestuurder, wat verant-woordelik en aanspreeklik is vir standaard- ontwikkeling in die verpleegdiens;

* in verpleegdiensbestuurder in die personeel-ontwikkelingsafdeling van die verplegings- diens;

* die verpleegkundige wat as ' $\mathrm{n}$ praktykkundige in ' $n$ verplegingseenheid funksioneer;

* verpleegdiensbestuurders en hoofverpleegkundiges wat ondersteuning en begeleiding aan verpleegkundiges in verplegingseenhede verleen;

* die subgroepe wat uit verskillende lede van die multiprofessionele span in ' $n$ hospitaalgemeenskap bestaan;

* verpleegdiensbestuurders in die proses van standaardisering en formalisering van standaardontwikkeling.

Die verhouding tussen hierdie rolspelers impliseer dat die verpleegdiensbestuurder ' $n$ indirekte rol vervul in die fasilitering van gehalteverpleging. Hierdie gedeelde funksie impliseer dat alle verpleegdiensbestuurders verantwoordelik en aanspreeklik is vir gehalte-bestuursuitsette. Gehaltebestuursuitset te impliseer gehalteverpleging en gehaltepersoneelontwikkeling. Die verpleegdiensbestuurder is dus verantwoordelik vir die hersosialisering van verpleegkundiges ten opsigte van gehalteverpleging. Afhangende van die grootte van die hospitaalgemeenskap en die aantal verpleegkundiges werksaam in die hospitaal, is daar ' $n$ aparte personeelontwikkelingsafdeling met ' $n$ verpleegdiensbestuurder aan die hoof, wat bystand kan verleen in die fasilitering van gehalteverpleging.

Die spesifieke akademiese hospitaal bestaan uit verplegingseenhede vir verloskundige, pediatriese, sjirurgiese en mediese verpleging.
Hierdie verplegingseenhede wissel van operasiesaalverpleging, intensieweverpleging tot buitepasiënt- en distriksdienste. Die doelstellings van al die verplegingseenhede is verskillend, maar verpleegkundiges in beheer van verplegingseenhede is verantwoordelik en aanspreeklik vir die gehalte van verpleging wat gelewer word.

Die eerste stap in gehalteverbetering is die stel van spesifieke standaarde vir verplegingseenhede. Omdat standaardontwikkeling ' $n$ gestruktureerde proses is, word dit in die personeelontwikkelingsafdeling deur die verpleegdiensbestuurder gefasiliteer. Die projek vir "die ontwikkeling van verplegingstandaarde" sal onder die vyf konsepte verbintenis, voorbereiding, ontwikkeling, standaardisering en formalisering van standaarde beskryf word.

\section{a) Verbintenis}

Die hoofverpleegdiensbestuurder het die eerste vergadering toegespreek, wat deur twee hoofverpleegkundiges belê is, nadat hulle ' $n$ lys saamgestel het met verpleegkundiges wat hulle geïdentifiseer het vir hierdie projek. Die eerste groep het uit tien verpleegkundiges van tien verplegingseenhede, wat nie noodwendig eenheidsbestuurders was nie, bestaan. Daar was ook geen navrae ten opsigte van die projek nie omdat die projek deur die hoofverpleegdiensbestuurder geïnisieer is.

Inligting wat tydens hierdie vergadering verskaf is, was dat die groepe een maal per week op ' $n$ Woensdag bymekaar sou kom. Hierdie vergadering sou een uur duur en die twee hoofverpleegkundiges sou as koördineerders vir die opstel van die prosedures optree. 'n Derde hoof verpleegkundige het ook by die ander twee as koördineerders aangesluit. Bestuursverbintenis was in die beginstadium dus bevredigend.

\section{b) Voorbereiding}

Die kursusinhoud vir die formulering van verplegingstandaarde het hoofsaaklik bestaan uit groepsdinamika en die basiese beginsels van navorsing. Die koördineerders wou eers die individu ontwikkel voordat daar sprake van die ontwikkeling van prosedures kon wees. Die kursus sou ses weke in totaal duur, en lesings is deur die verpleegdiensbestuurders van die hospitaal aangebied.

Vir die aansluiting by die groep en ook vir die skryf van die prosedures (prosesstandaarde) was daar geen spesifieke kriteria of formaat nie. Hierdie aktiwiteite het alles buite die personeelontwikkelings-afdeling in die verplegingseenhede plaasgevind en die personeel in die personeelontwikkelings-afdeling was nie betrokke by die projek wat in die hospitaal geloods is nie. Verpleegkundiges wat gevra is om by die groep aan te sluit, kon voorstelle indien vir die prosedures wat hulle wou skryf.

Probleme wat in die beginstadium van die projek ondervind is, was verpleegkundiges wat met vakansie en siekverlof gaan, die verplegingseenhede wat te besig was, verpleegkundiges wat dae af gehad of nagdiens gewerk het, en stakings wat die dienste beïnvloed het.

Oplossings wat voorgestel is, was dat die hoofverpleegkundiges van die spesifieke area waar die verpleegkundige gewerk het, haar/sy funksie vir die uur se afwesigheid op ' $n$ Woensdag sou oomeem en dat afdienstye en verlof so gereël behoort te word dat dit nie die ses weke van die kursusbywoning sou beïnvloed nie.

In Februarie 1992 het die navorser vir die eerste keer enkele insette ten opsigte van die formulering van ' $n$ filosofie, doelstellings en doelwitte en die formaat van prosedureontleding gelewer. Verpleegkundiges sou nou ' $n$ filosofie vir die groep formuleer en die formaat wat uit 'n struktuur-, proses- en produkstandaard bestaan het, implementeer.

Op hierdie stadium is daar ook ' $n$ versoek gerig aan die hoofverpleegdiensbestuurder om die kursus as 'n formele driedaagse kursus aan te bied, met verpleegkundiges wat vrygestel word van funksionele aktiwiteite in die eenhede. Die driedaagse kursus vir die ontwikkeling van verplegingstandaarde is vir die eerste keer in April 1992 geïmplementeer.

Aan hierdie projek het 45 verpleegkundiges deelgeneem. Dertien verpleegkundiges het die driedaagse kursus voltooi, die proses van standaardontwikkeling geïmplementeer en groepe gevorm en standaarde ontwikkel. Die totale aantal verpleegkundiges, as deel van die groepe, wat 'n suksesvolle bydrae vir die 40 spesifieke kliniese standaarde gegee het, is 28 .

\section{c)Ontwikkeling}

Ontwikkeling van verplegingstandaarde het nie volgens gestruktureerde groepe in die verplegingseenhede plaasgevind nie, maar daar is wel van verpleegkundiges gebruik gemaak wat belang gestel het om insette te lewer. Onder begeleiding van die hoofverpleegkundiges het die verpleegkundiges prosedures geformuleer wat aan die neergelegde vereistes van die hoofverpleegkundiges voldoen het. $\mathrm{Na}$ implementering van die driedaagse kursus vir die ontwikkeling van verplegingstandaarde het die vereistes verander na wetenskaplike kriteria uit die literatuur.

Verpleegkundiges wat hulle prosedures voltooi het, moes dit voordra en demonstreer aan ' $n$ groep van ongeveer 10 genooide verpleegkundiges. Die hoofverpleegkundiges sou die prosedures en aanbieding evalueer aan die hand van ' $n$ kontrolelys wat hulle saamgestel het. In Julie 1992 het die een hoofverpleegkundige bedank as koördineerder van die groep, en die ander twee hoofverpleegkundiges het die projek met behulp van die navorser voortgesit. ' $n$ Opedag is beplan vir April 1993. Ongelukkig moes die datum met ' $n$ maand vervroeg word en ook die tweede hoofverpleegkundige het in Februarie 1993 as koördineerder bedank. Tot op datum is ' $n$ totaal van 40 spesifieke kliniese standaarde by die navorsingshospitaal ontwikkel. (Sien lys onder formalisering.) 


\section{d) Standaardisering}

Terselfdertyd is ' $n$ standaardiseringskomitee saamgestel wat hoofsaaklik bestaan het uit vier verpleegdiensbestuurders, die infeksiebeheerpraktykkundige verpleegkundige en 'n professionele verpleegkundige wat verantwoordelik was vir die vrystelling van hospitaalbeleid in die verplegingseenhede. ' $n$ Senior dosent van die verplegingskollege het ook in die standaardiseringskomitee gedien.

In Maart 1992 is die navorser genader om as lid in die standaardiseringskomitee te dien en ' $n$ evalueringsinstrument vir die aktiwiteite van die komitee saam te stel. Die standaardiseringskomitee met die vier verpleegdiensbestuurders het as gevolg van persoonlike redes verminder tot net een verpleegdiensbestuurder.

\section{e) Formalisering}

Formalisering van die projek het deur middel van 'n opedag plaasgevind, met verpleegkundiges wat aan die projek deelgeneem het. Hulle het hulle standaarde gedemonstreer aan die verpleegpubliek wat die opedag bygewoon het. Ongeveer " $n$ duisend verpleegkundiges van die Transvaalse streek het die opedag bygewoon. Formalisering van die projek is verder bevestig met ' $n$ handleiding met die ontwikkelde standaarde wat aan verplegingseenhede verskaf is en die publisering van ' $n$ boek met hierdie standaarde wat as ' $n$ riglyn vir ander gesondheidsdienste kan dien.

Indiensopleiding vir die bekendstelling van hierdie standaarde na die ope dag word beskou as die funksie van die verpleegkundige wat dit ontwikkel het en die personeel in die personeelontwikkelingsafdeling. Huidig het verpleegdiensbestuur geen aandeel hieraan nie.

\section{Standaarde oor die volgende}

verpleeginteraksies is geformuleer:

* aspekte oor sentraal-veneuse druk

* koppeling van die pasiènt aan die hemodialise masjien

* voorbereiding van parenterale voeding

* rug en drukplekversorging

* mondversorging

* die aanwending van veltraksie

* nebulisasie

* stomaverpleging

* holistiese standaarde vir die netropeniese pasiënt

* glukose bepaling

* insulin toediening

* bloeddrukbepaling

RESULTATE IN DIE EVALUERING VAN DIE PROJEK: DIE FORMULERING VAN VERPLEGINGSTANDAARDE

(Operasionalisering van die model)

Evaluering van die projek vir die formulering van verplegingstandaarde sal beskryf word volgens die direkte evaluering van die inteme groep asook die navorser se evaluering. Die respondente se aanhalings word direk in Engels of Afrikaans weergegee.

\section{Direkte weergawe van evaluerings}

Ontleding van die inhoud verkry uit die vraelys het die volgende opgelewer, soos direk vanuit die vraelyste weergegee.

\section{Respondent een:}

"Myself: It motivated me to write standards on other procedures in the unit, and it gave me an interest in quality assurance and administration. Hospital: It has a challenge as it involved staff who had not previously done this type of work/research and staff who were enthusiastic personnel but others dropped out once they realized how much work was involved. To get the full benefit of this program, I think an intense inservice program in all areas about these standards should be implemented and it should involve all the clinical staff."

\section{Respondent twee:}

"Involvement in the project was experienced as stimulating, enriching, exciting and revealing. It was a privilege to be involved in the teams and teamwork within the multidisciplinary group. Most rewarding seeing and realising the development and achievement of individuals and self. Would not have missed being part of the project for all the money in the world!!"

"Positive aspects were:

1.Multidisciplinary teams over a broad spectrum were forced to hamess specialist and consultant expertise and knowledge:

* Assisting in bringing about cohesion amongst different groups and individuals (patients, GAs, dieticians, medical reps, physios, doctors and all categories of nurses).

* Forcing recognition of other resources, knowledge and skills needed in order to obtain validity - very humbling.

* Creates an awareness, realisation of the inevitable shortcoming and improvement needed within areas over sphere of practice (because more critical of one's self and performance).

* Broadens your outlook - combating severely the most obstructive and destructive element of (R.T.C.) reluctance to change!!

* Forces one to look at the medical representative product specialist as a source of knowledge enhancing correct product utilisation to the mutual benefit of all, conserved patient, nurse, need rep and product!

* Realisation of self-worth and esteem booster -each has a very valuable contribution to make.

* Foresees the people involved at present to bring current practice to the fore to be showed to all, especially those out of touch. These are the people to be developing standards.
* Motivating! breaks dull routine and sometimes futile efforts to achieve change.

* Exposure to all important group dynamics group interaction -developing and recognising leadership learning about oneself and others.

* Project members presented concepts, standards winning prizes and recognition in outer circles - sadly no local recognition.

* Need for research and extensive reading -developing an enquiring mind.

2.The Open Day, March 1993, most rewarding - exposure of people who matter, to teaching and experts as consultants and specialists in their field. Exposure of medical representatives they experienced the event as very positive regarding exposure and the ensuring cooperation amongst groups.

\section{'Negative aspects:}

* Hard work - hampered by strikes.

* Most of all - lack of support from management and no interest or input at any level. There appears to be no recognition as project being a factor considered in meriting - demoralising and very destructive element.

* A feeling of resentment - ? reason. It was stated that standards are written - wards are poor. Surely this would be one very valuable means of motivating and bringing about openness and awareness!!?? Attitude change is vital.

* Slow process - but the ripple is there, evidenced by all above."

\section{Respondent drie:}

"The group project commitment to team consensus in addition to accuracy and clarity in the development of standards enhanced the dynamics of a well-established and functional team which forms an integral component of chronic disease management.

Participation in the project to develop nursing standards added a meaningful dimension to chronic disease management and provided structure for evaluation and remediation.

The nursing standards encourage self evaluation and challenge nurses to perform consistent and quality nursing actions."

\section{Respondent vier:}

"Holistic nursing care - it is a whole new way of thinking for me and I was not always sure whether my brain could attune or not! It had been an incredible amount of work and at times I found it quite stressful fitting it around an already busy schedule. Keeping tabs on nine different projects was quite a challenge. I met many different people in the hospital and learnt to work with them all, especially my colleagues when the project first started and we were 
preparing for Open Day. I now look at the neutropaenic patients and mentally go through a check-list of their requirements, and encourage colleagues to do the same. It has helped me in the teaching that I do as I feel confident to discuss the areas that have been researched. I look at written work far more analytically and have learnt to speed proof-read. I have an enormous respect for computers and those who operate them. I have been able to co-present the Philosophy in Cape Town in September I993 at the Symposium on Nursing Education. I have had an abstract concerning the Philosophy accepted for presentation in Vancouver in August 1994. I have a great respect for the persons who were offered the idea and had the foresight and determination to see it through this far.

With the project in mind, I have been out to focus on various aspects of holistic care of the neutropaenic patient and have been able to implement several of the topics during my teaching: the education of the cleaning staff in the wards relative to protective isolation; the use of leucocyte blood filters and platelet filters as part of the administration of blood products; meeting regularly with the therapeutic dieticians when addressing the nutritional needs of the patients; including the hands-on professional nurses in the medical wards when compiling the Hickman line project; lectures on chemotherapy - emphasising the safe administration thereof; working closely with the social workers to provide psychosocial care; involving the physiotherapists to encourage an improved service; creating a relationship with the experimentalist who has valuable advice to offer, I value the input Prof $B$ has given and feel that he has an understanding that the need of his patients will be better dealt with once the projects are available in the wards; I will feel a greater sense of achievement and accomplishment when I know that the projects are in the wards, as then the knowledge will be implemented and the "Group" will have come a full circle; finally, I think that the "group" is already starting to show that the team approach in implementing standards will provide quality nursing care."

\section{Respondent vyf:}

"The project gave the direction in leading a small group. The principals of nominal group technique were new to me and I was astonished at my own ability to lead a group. Up till then I had always felt that I would be unable to. I felt, given the opportunity (and the youth), I could effectively have run a department.

The project was a means of establishing ideal standards in a situation where standards are plummeting. The project reestablished the priority of the nurse, which is excellence in patient care. I was proud to be part of it."

\section{Respondent ses:}

"A taste of research; to discover what articles had been written about the topic I was researching. To leam more about traction and to help establish a standard which will be issued to wards and hopefully ensure the optimum patient care will be given; a chance to work with other professionals who have the same goals and standards as I have. At the hospital: a raising of nursing standards as long as they use the information supplied."

\section{Respondent sewe:}

"In the beginning it sounded like a very interesting short-term project. It then became a long, time-consuming project which demanded most of my spare time. It was very frustrating at some stage caused by lack of information. Most books only mentioned the toothbrush irrigation method in headings only. Most of the information needed thinking and checking with other people.

At times giving up somnded like the best solution. There was a lot of growing up and increasing one's knowledge. After what seemed like a long time it was over. Then came the open day. There were few of us presenting in front of a large crowd. The open day went very well. When letters of congratulations and requests to present in other hospitals came, I felt very proud of myself and the whole project team. It improved nursing standards in the hospital."

\section{Respondent agt:}

"Project improved my: perspective; confidence; coping-back-up; focus; Confidence - with the setting of standards I found new strength in my teachings/consultations in all aspects of the nursing field. Coping/Perspective - I find that my aim is very clear and that I do not feel threatened by more knowledgeable doctors/tutors. I have the means of setting goals rationally as well."

\section{Respondent nege:}

"Having accepted to become part of the Group project to improve nursing standards, it soon became an obvious and interesting challenge. Having researched a project such as this made me realise how important it is for future quality assurance in the nursing profession. It has also motivated me to improve my own image by being instrumental in the growth and development of our future nursing colleagues. Standardisation has taken a firm grip on my life, with the result that I am now continuously trying to research other procedures in my own department.

Striving for excellence and implementing quality assurance in our hospital was the ultimate purpose of the group project as observed by myself. This purpose motivated me to pursue and persevere in sometimes very difficult circumstances to complete my project, to ultimately be a provider of a quality nursing procedure. This project meant many late night hours at home, many hours of research, but the final product proved worthy of all the effort. Unfortunately it would appear that very little recognition is given by the remainder of senior professionals, who do not take the slightest interest in a group of people who are now in consulting positions on certain nursing aspects. One wonders how quality assurance can be gained if there are no support and encouragement given to those who tried so hard to improve the nursing standards in the hospital. After all, quality is the concern of everyone who provides a service and everyone who uses that service."

\section{BESPREKING VAN RESULTATE}

Dit blyk dat die ontwikkeling van verplegingstandaarde en die daaropvolgende implementering van die standaarde wel gehalteverpleging fasiliteer en is deur sewe van die nege verpleegkundiges in hulle evaluering bevestig en beskryf. Dit word erken dat hierdie evaluering van gehalteverpleging nie formeel aan die hand van die standaarde plaasgevind het nie, maar gebaseer is op die persepsies van die deelnemers.

Die laaste aspek wat geëvalueer is met die ontwikkeling van verplegingstandaarde, naamlik die hersosialisering van waardes, is ook deur sewe respondente positief bevestig.

Ten opsigte van professionele en persoonlike ontwikkeling het al nege respondente professionele en persoonlike ontwikkeling ervaar met die ontwikkeling van verplegingstandaarde.

\section{GEVOLGTREKKING}

Uit bogenoemde resultate word die sentraalteoretiese aanname ondersteun, naamlik die ontwikkeling van verplegingstandaarde deur die verpleegkundige fasiliteer gehalteverpleging, die hersosialisering van waardes, en professionele en persoonlike ontwikkeling in "n spesifieke hospitaalgemeenskap. Hierdie praktykmodel het dus funksionele waarde.

\section{DIE NAVORSER SE EVALUERING VAN DIE IMPLEMENTERING VAN DIE VOORLOPIGE MODEL VIR DIE ONTWIKKELING VAN VERPLEGINGSTANDAARDE}

Die navorser sal haar subjektiewe evaluering van die uiteindes van die voorlopige model vir die ontwikkeling van verplegingstandaarde beskryf volgens die doelstelling van die model, naamlik die fasilitering van gehalteverpleging, die hersosialisering van waardes, en die professionele en persoonlike ontwikkeling van verpleegkundiges.

Alhoewel daar volgens die praktykkundige verpleegkundiges ' $n$ waameembare verbetering in die eenhede is, is daar nooit ' $n$ formele evaluering van standaarde gedoen nie en word dit huidig as ' $n$ leemte in die proses van gehalteverbetering by die navorsingshospitaal ervaar.

Die. fasilitering van gehalteverpleging is duidelik te bespeur in die uiteindes van die standaarde wat geimplementeer is in stomaverpleging. Nie net die stomaterapeut nie, maar ook haar studente en verpleegkundiges in 
die verplegingseenhede het duidelike geskrewe riglyne in die hantering van enige van die verplegingstoestande waarvoor standaarde ontwikkel is. Dit is ook voortdurend sigbaar hoe die stomaterapeut demonstrasies en verduidelikings van aksies gee met die geskrewe standaard byderhand sodat verpleegkundiges haar aksies kan volg en haar terselfdertyd kan evalueer soos wat sy hulle gaan evalueer.

Met die implementering van hierdie nuwe standaarde het daar onder die betrokke verpleegkundiges ' $n$ nuwe positiewe houding ontstaan. Omdat daar geskrewe voorskrifte vir die verpleging van stoma-toestande is, kom verpleegkundiges meer selfversekerd voor en het daar dus ' $n$ hersosialisering van waardes ten opsigte van gehalte-stomaverpleging plaasgevind. Vir die navorser was dit duidelik om die professionele en persoonlike ontwikkeling in die stomaverpleegkundige waar te neem. Sy tree met ' $n$ nuwe selfversekerdheid en ' $n$ selfhandhawende houding teenoor personeel van alle range op.

Die uitbeelding van die stomaverpleegkundige se persepsie van gehaltestomaverpleging op " $n$ plakkaat, het aan haar die eerste-prys op ' $n$ stomakongres in die Kaap besorg. Hierdie plakkaat sal ook eersdaags in ' $n$ internasionale tydskrif vir stomaverpleging verskyn en die nasionale vereniging vir stomaverpleging gaan die plakkaat as deel van hulle uitstalling in Japan op die internasionale kongres gebruik.

Die verpleegkundige wat die standaarde vir die heelheids-benadering van neutropeniese pasiënte ontwikkel het, verbaliseer dat die gehalte van verpleging in haar area verbeter het omdat sy samewerking van haar kollegas het. Ook is die geneeshere bewus van die verplegingstandaarde. Spanwerk het verbeter en eienaarskap van standaarde word deur die verpleegkundiges wat dit ontwikkel het, erken. As gevolg hiervan het verpleegkundiges onbewustelik ' $n$ hersosialisering van waardes ten opsigte van die nuwe standaarde ondergaan.

Dit was ook bemoedigend om die selfvertroue en die selfhandhawendheid in die leier, verpleegkundige, te bespeur. Tydens ' $n$ kongres in die Kaap het die kongresgangers haar insette feitlik woord vir woord afgeskryf, en gedurende vraetyd wou hulle meer weet van haar belewenis en implementering van die projek wat sy effektief hanteer het. Haar aangehaalde uittreksel vir die toepassing van die filosofie vir die ontwikkeling van verplegingstandaarde vir die neutropeniese pasiënt is aanvaar vir 'n kongres in Vancouver in Augustus 1994. Die professionele en persoonlike ontwikkeling van hierdie verpleegkundige is in al hierdie aktiwiteite duidelik sigbaar.

Die hoofverpleegkundige wat saam met die navorser die projek vir die ontwikkeling van verplegingstandaarde geïmplementeer het, se professionele en persoonlike ontwikkeling is van so ' $n$ aard dat sy as ' $n$ kundige op die gebied van die ontwikkeling van spesifieke (kliniese) verplegingstandaarde beskou kan word. Volgens die evaluering van die verpleegkundiges in die kursusse het sy ook al die lesings wat deur die verpleegdiensbestuurder gegee word, suksesvol aangebied. Wat die formaat en ontwikkeling van die verplegingstandaarde betref, is sy heeltemal vertroud daarmee en het saam met die navorser opgetree as mederedakteur van die handleiding vir die verplegingseenhede en die boek vir die eksterne verplegingsgemeenskap wat gepubliseer is. Na haar aftrede word sy nog steeds gebruik as medekonsultant vir die validering van verplegingstandaarde.

Die verpleegkundige wat die mondversorgingstandaard ontwikkel het, word tans gebruik as ' $\mathrm{n}$ konsultant in gemeenskapstandheelkunde en het haar standaard ook effektief in haar verplegingseenheid geïmplementeer met die gevolglike verbetering van die gehalte van verpleging en die noodwendige hersosialisering van verpleegkundiges se waardes ten opsigte van mondversorging.

Met die laaste kongres oor diabetiese verpleging het die verpleegkundige wat diabetiese verpleegstandaarde ontwikkel het, die prys vir die beste referaat gekry en, soos sy dit gestel het, dit was as gevolg van haar navorsing en betrokkenheid by die ontwikkeling van verplegingstandaarde. Hierdie standaarde is ook in haar eenheid geimplementeer en het blykbaar sowel die gehalte van die verpleging verbeter as verpleegkundige waardes gehersosialiseer.

Die projek oor die ontwikkeling van verplegingstandaarde het een verpleegkundige so geïnspireer dat sy begin het met standaardisering in haar verplegingseenheid. Vierdejaar-verpleegkundiges wat haar eenheid geëvalueer het, het geverbaliseer dat hulle nie kon glo dat teorie so in die praktyk geïmplementeer kan word nie.

Nie net professionele en persoonlike ontwikkeling maar die basis vir gehalteverpleging en die hersosialisering van waardes is in hierdie verpleegkundige gevind. Die verpleegkundige wat die hemodialisestandaard ontwikkel het, kon die terminologie wat die navorser tydens die driedaagse kursus gebruik het, aanvanklik baie moeilik internaliseer. Die hoofverpleegkundige het letterlik ' $n$ uur met haar oor die telefoon gekommunikeer om ondersteuning en hulp aan te bied. Met die fmale standaard het die navorser gevra dat dié verpleegkundige die standaard en die evalueringsinstrument kombineer. Binne vier en twintig uur het hierdie verpleegkundige die gekombineerde standaard aan die navorser terugbesorg. Min van die verpleegkundiges kon hierdie gekombineerde standaardevalueringsinstrument 'n eerste keer korrek weergee. Hierdie verpleegkundige het wel!

Tydens die teepartytjie wat vir die verpleegkundiges wat standaarde ontwikkel het deur die personeel van die personeelontwikkelingsafdeling gereël is, het hierdie verpleegkundiges ingestap en die teepartytjie volgens struktuur-, proses- en produkstandaarde geëvalueer. Dit was 'n duidelike teken van optimale internalisering. As die taalgebruik van die verpleegkundiges in die evaluering van die projek geanaliseer word, is die terminologie nie net verstaanbaar nie, maar het die verpleegkundiges getoon dat hulle gehalteverbetering geïnternaliseer het.

Dit is nie net die praktykkundige verpleegkundiges wat professionele en persoonlike ontwikkeling tydens die projek vir die ontwikkeling van verplegingstandaarde ondergaan het nie, maar ook die navorser. Om hierdie projek effektief te kon implementeer, is daar baie naslaanwerk gedoen. Kontrolelyste moes vir elke aktiwiteit van die projek opgestel word, en ' $n$ formaat saamgestel word. Die voortdurende remediëring van standaarde het ' $n$ basis vir die eindresultaat gevorm. Die verskillende kliniese standaarde het die navorser gedwing om kliniese naslaanwerk te doen en dit het veroorsaak dat die navorser se kliniese kennis nie net toegeneem het nie, maar op datum is met die nuutste navorsing.

Die verpleegkundiges wat deelgeneem het aan die projek, was nie die enigste wat professionele en persoonlike groei ondergaan het nie. Die eerste tikster wat ingekoop is, het foute met die tegniese versorging geremedieër en die verpleegkundiges daarop attent gemaak. Wanneer werk nie vir haar sin gemaak het nie, het sy dit bevraagteken.

Ander personeel in die afdeling wat ook baat gevind het by die projek is die hulppersoneel, naamlik die algemene assistente. Hulle was verantwoordelik vir die fotostatering van die standaarde en het baie gou besef dat net die beste gehalte aanvaarbaar was. Op eie inisiatief het hulle die beste fotostaatmasjien in die hospitaal opgespoor. Aan hulle is verduidelik dat hierdie ' $n$ spanpoging is en hoe belangrik hulle effektiewe funksionering is.

\section{OPSOMMING}

Die sentraalteoretiese aanname, naamlik dat die ontwikkeling van verplegingstandaarde gehalteverpleging, die hersosialisering van waardes en asook professionele en persoonlike ontwikkeling by verpleegkundiges fasiliteer, word op 'n subjektiewe wyse ondersteun deur hierdie evaluering. ' $n$ Meer formele evaluering deur middel van die ontwikkeling en implementering van ' $n$ formele gehalteverbeteringsprogram in elk van die eenhede sal uitgevoer word.

\section{AANBEVELINGS}

Die volgende aanbevelings word gemaak:

* die verdere uitvoering van die formele proses van gehalteverbetering in die verpleegdiens deur die ontwikkeling en implementering van toepashke monitering- en evalueringstelsels;

* formele hipotesetoetsing gebaseer op die sentraalteoretiese aannames, naamlik dat die 
ontwikkeling en implementering van verplegingstandaarde die gehalteverpleging in die verpleegdiens verhoog, die hersosialisering van waardes oor gehalte onder verpleegpersoneel fasiliteer, asook positiewe persoonlike en professionele ontwikkeling by die verpleegkundiges laat plaasvind.

\section{ERKENNING}

Hierdie studie is gedoen as deel van ' $n$ doktorale proefskrif by die RAU, met dank en erkenning aan die verpleegkundiges wat deelgeneem het.
VERWYSINGS

AFFARA, A. \& STYLES, M.M. (1991): Nursing regulation: from principle to power. Geneva: International Çouncil for Nurses.

AMERICAN NURSES ASSOCIATION, (1975): A plan for implementation of the standards of nursing practice. Kansas City: American Nurses Association Publication.

AMERICAN NURSES ASSOCIATION, (1975): Standards for continuing education in nursing. Kansas City: American Nurses Association Publication.

SCHUERMAN, J.R. (1983): Research and evaluation in the human sciences. London: Collier McMillan Publishers.

SWANSBURG, R.C. \& SWANSBURG, P.W. (1984): Strategic career planning and development for nurses. Rochville: Aspen Publication.
WOODS, N.F.Y. \& CATANZARO, M. (1988): Nursing research. Theory and practice. St. Louis: C.V. Mosby.

VAN DER MERWE, T. (1994): 'n Model vir die ontwikkeling van verplegingstandaarde. JOHANNESBURG: RAU. Ongepubliseerde D.Cur Proefskrif.

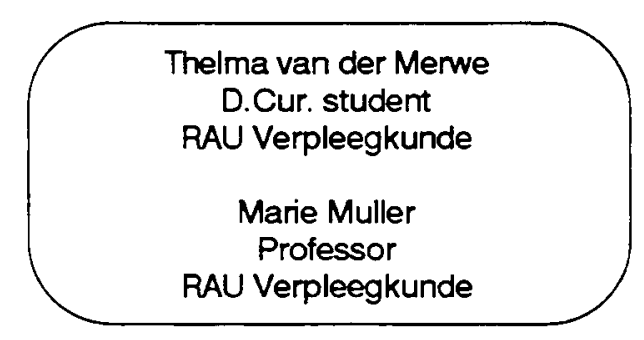

